\title{
The Impact of Makeshift Sandbag Groynes on Coastal Geomorphology: A Case Study at Columbus Bay, Trinidad
}

\author{
Junior Darsan $^{1} \&$ Christopher Alexis ${ }^{2}$ \\ ${ }^{1}$ University of the West Indies, St. Augustine Campus, Trinidad \\ ${ }^{2}$ Institute of Marine Affairs, Chaguaramas, Trinidad \\ Correspondence: Junior Darsan, Department of Geography, University of the West Indies, St Augustine, \\ Trinidad. E-mail: junior.darsan@gmail.com
}

\author{
Received: January 7, 2014 Accepted: February 7, 2014 Online Published: February 19, 2014 \\ doi:10.5539/enrr.v4n1p94 URL: http://dx.doi.org/10.5539/enrr.v4n1p94
}

\begin{abstract}
Coastal erosion threatens coastal land which is an invaluable limited resource to Small Island Developing States (SIDS). Columbus Bay, located on the south-western peninsula of Trinidad, experiences high rates of coastal erosion which has resulted in the loss of millions of dollars to coconut estate owners. Owing to this, three makeshift sandbag groynes were installed in the northern region of Columbus Bay to arrest the coastal erosion problem. Beach profiles were conducted at eight stations from October 2009 to April 2011 to determine the change in beach widths and beach volumes along the bay. Beach width and volume changes were determined from the baseline in October 2009. Additionally, a generalized shoreline response model (GENESIS) was applied to Columbus Bay and simulated a 4 year model run. Results indicate that there was an increase in beach width and volume at five stations located within or adjacent to the groyne field. The GENESIS model confirmed accretion within the groyne field and indicated a reduction in transport rates between groynes when compared to the rest of the bay to within $77.56 \%$ accuracy. This study revealed that the makeshift groynes though improperly engineered, has reduced coastal erosion by encouraging accretion. The GENESIS model can be a helpful tool to inform management decisions at Columbus Bay and other beaches and bays inTrinidad and Tobago.
\end{abstract}

Keywords: Columbus Bay, coastal erosion, sandbag groynes, GENESIS, coastal management

\section{Introduction}

Hard coastal engineering solutions include coastal structures such as; groynes, breakwaters, seawalls, revetments, etc. which may alter the shoreline and morphology of the beach (Elmoustapha et al., 2007) simultaneously influencing coastal processes (waves, currents etc.) and shoreline stability (Elsayed \& Mahmoud, 2007). These structures alter the erosion / accretion trend along the shoreline. Groynes are designed to stabilize the shoreline by; impeding littoral drift from an area of interest such as a harbour, reducing or abating erosion on a beach and impounding littoral drift sediment for the creation of a beach. The impoundment of sediment occurs updrift of the groyne and erosion occurs downdrift. Erosion and accretion rates depend on the amount of sediment available within the littoral cell. The mean grain size depends on; the type of sediment, wave energy and beach slope (USACE, 2006; Darsan, 2013a). Dissipative beaches are characterized by finest sediment and highest wave energies, while the reflective beaches contain coarser sediment and lower wave energies (Darsan, 2005, 2013b; Masselink \& Hughes, 2003). Deposition along a beach usually corresponds to decrease in mean grain size while erosion corresponds to an increase in mean grain size (Chauhan, Verma, \& Persad, 1988).

Installation of coastal structures and their associated impacts were highlighted by Black (2001), Nielsen (2001), Basco and Pope (2004), Kraus and Rankin (2004), USACE (2006), Kökpinar, Darama, and Güler (2007), Elsayed and Mahmoud (2007). More recently, Mohanty et al. (2012) investigated the impact of groins on beach morphology along the east coast of India. Research on the impact of groyne parameters on shoreline evolution has been conducted using physical and numerical modelling approaches (Elmoustapha et al., 2007; Kökpinar, Darama, \& Güler, 2007; Elsayed \& Mahmoud, 2007). Research by USACE (1977), Ehrlich et al. (1982), Perlin and Dean (1983), Hanson and Kraus (1989), USACE (1995), French and Livesey (2000), Reeve, Chadwick, and Fleming (2004), Griggs (2004), Kraus and Rankin (2004), USACE (2006), Mohamed and Mahmoud (2007) and Kökpinar, Darama, and Güler (2007) have shown that numerical modelling favourably evaluated coastal structures such as groynes. 
There have been several studies conducted on the erosion at and in the vicinity of Columbus Bay. Deane (1973) observed and commented on the influence of swell and wave refraction patterns on the shoreline of Columbus Bay. He noted an erosion rate of $4.11 \mathrm{~m} / \mathrm{yr}$ at Corral Point, with no erosion at Los Gallos, and recommended that a long groyne be installed to the 2 fathom mark. Oostdam (1982) conducted a comprehensive study on the sediment within the bay and along the shoreline. He found that finer sediment was found closer to the Los Gallos headland with sediment size increasing to the southern end of the bay, with an erosion rate of $10 \mathrm{~m} / \mathrm{yr}$ at Corral Point. Kenny (2002) executed a shoreline comparison study using orthophotographs and aerial photography over various epochs, and found an erosion rate of $4 \mathrm{~m} / \mathrm{yr}$ at Corral Point, and was the first to document accretion of 3 $\mathrm{m} / \mathrm{yr}$ at Punta del Arenal. Kanhai (2009) used Arc GIS to compare shoreline regression and transgression along the entire south western peninsula of Trinidad. Kanhai (2009) calculated an erosion rate of $1.2 \mathrm{~m} / \mathrm{yr}$ at Corral Point, and $1.67 \mathrm{~m} / \mathrm{yr}$ at station 7 in the middle of Columbus Bay, and recommended that headlands be installed along the bay. Most recently, Darsan et al. (2012) through the analysis of beach profiles calculated an erosion rate of $2 \mathrm{~m} / \mathrm{yr}$ at station 7 in Columbus Bay.

For this study, the STWAVE module of the CEDAS numerical models simulated nearshore wave conditions at Columbus Bay with and without groynes, while the GENESIS module computed shoreline evolution. Based on the effectiveness of the groynes inclusive of differences in shoreline response, the appropriateness of the structures was evaluated. This paper evaluates the effectiveness of three sandbag groynes at Columbus Bay, Trinidad. While this bay has been studied by several researchers in the past, this is the first attempt to numerically model the Columbus Bay shoreline response to groynes.

\section{Study Area}

\subsection{Coastal Setting}

Trinidad and Tobago is situated in the southernmost end of the Caribbean island chain between $10^{\circ} 02^{\prime}-10^{\circ} 50^{\prime} \mathrm{N}$ latitude and $60^{\circ} 55^{\prime}-61^{\circ} 56^{\prime} \mathrm{W}$ longitude. It is located on the continental shelf of South America, and immediately adjacent to the outflow of the Orinoco River. The country is less exposed to tropical storms and hurricanes than most of the Caribbean nations because of its southerly location, and has a tropical marine climate with two distinct seasons. The dry season occurs between January and April, while the wet season extends from June to November. May and December are considered transitional months between the two seasons (Henry, 1990). The wet season is heavily dependent on the Inter Tropical Convergence Zone. Within the wet season there is a period of weather with the characteristics of the dry season between the months of September to October. This period is referred to as Petit Careme (McSweeney, New, \& Lizcano, 2008). Columbus bay is located at latitude $10^{\circ} 4{ }^{\prime} 60^{\prime \prime} \mathrm{N}$ and longitude $61^{\circ} 55^{\prime} 0^{\prime \prime} \mathrm{E}$ along the west coast of Trinidad (Figure 1). The south-western peninsula of Trinidad is currently being considered for development as a growth pole by the Government of the Republic of Trinidad and Tobago. 


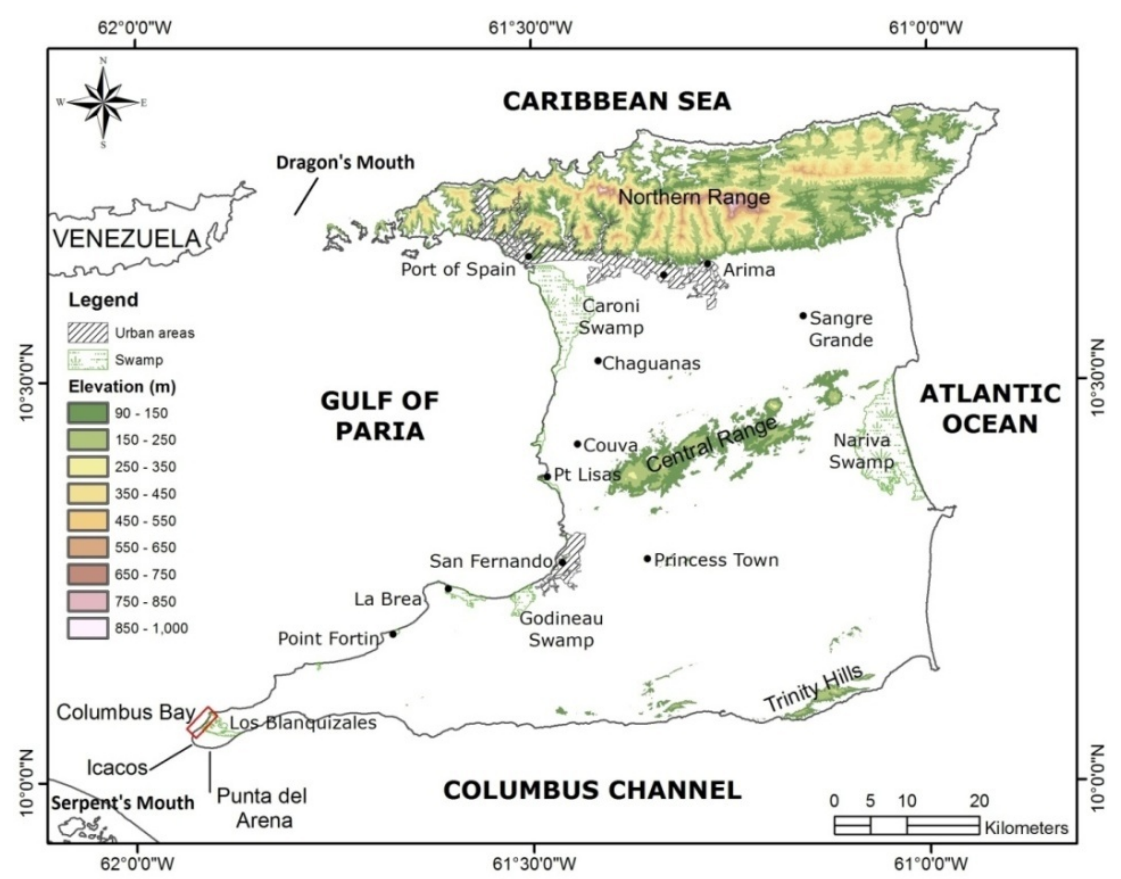

Figure 1. Study location - Columbus Bay, Trinidad

The oceanic current flow in the vicinity of Trinidad and Tobago is influenced by the North Brazil Current (NBC), a western boundary current that influences the entire Caribbean. The NBC rings, swirl anticyclonically at speeds approaching $1 \mathrm{~ms}^{-1}$, while translating north-westward towards the Caribbean on a course parallel to the South American coastline (Fratantoni \& Richardson, 2006). They collide with the Lesser Antilles Passages, and the ring fragments drift westward into the Caribbean, resulting in mesoscale eddies, and meanders with diameters of $100-500 \mathrm{~km}$.

Trinidad and Tobago are influenced by the South Equatorial Current inclusive of the Guiana Current which flows around the north-eastern perimeter of South America. This strong oceanic current attains a maximum speed of approximately 4.2 knots and has an average speed of approximately 2.4 knots (Febres-Ortega \& Herrera, 1976). The Guiana Current deflects some of the South American river inputs, including that of the Orinoco delta, along its path toward Trinidad and Tobago. The differentiation of the water masses within the Gulf of Paria was made after monitoring the salinity and temperature fluctuations within the water column (Van Andel \& Postma, 1954). These fluctuations are heavily reliant on the fresh water discharge of the Orinoco River which gives rise to variations of densities and results in circulation (Van Andel \& Postma, 1954). It was concluded that the circulation pattern of the water masses within the Gulf of Paria creates a clockwise gyre. This gyre is formed as a result of the flow of water through the Serpent's Mouth (between Trinidad and South America) from the North Brazil Current and the Guiana Current (Gopaul \& Wolf, 1995).

The tidal regime is that of a mixed semi-diurnal type, influenced by tide waves from the Caribbean Sea and the Atlantic Ocean (Henry, 1990; Darsan et al., 2013). The tide wave enters the Gulf of Paria via the Dragon's Mouth approximately thirty minutes before the tide wave which enters the Serpent's Mouth. As a result of the time difference, the tide within the Gulf of Paria is controlled by the tide wave from the north (Van Andel \& Postma, 1954).

Some waves occur as a result of the action of trade winds on the water's surface, storms and squalls throughout the hurricane months and swell waves originating from the North Atlantic which immigrate into the Gulf of Paria These waves affect the littoral processes along the south western coasts of Trinidad (Deane, 1973). These waves may impact the shoreline at large angles from the east and may be the reason for considerable littoral drift to the west.

\subsection{Study Area}

Columbus Bay is located on the south-west peninsula of Trinidad and has a narrow beach $(2 \mathrm{~m})$ backed by a 0.30 $\mathrm{m}$ scarp (Sabastien, 2010). The beach is approximately $4000 \mathrm{~m}$ in length and is composed of geologically young sediments inclusive of alluvium, silt and greyish-brown, medium-grained, quartz rich sand which are susceptible 
to the impact of coastal processes (Oostdam, 1982). The bay is bounded by Los Gallos Point (a headland) to the north and by Corral Point to the south. The headland (5 m-15 m high cliffs) is part of the Morne L' Enfer formation and comprises mainly easily erodible sandstone sediment inter-bedded with siltstones and clay-shales (GSTT, 1997) with varying extents of mineralization as evidenced by three stacks 'the sisters' - remnants of a once prominent headland (Oostdam, 1982). The bay has a concave shape and is oriented northeast to southwest. There are two mangrove systems within this bay: the Los Gallos system in the north and the Icacos system in the central region (Juman and Ramsewak, 2010). The geology and the orientation of the bay make it susceptible to erosive forces, i.e. winds, waves and weathering (Oostdam, 1982). The Columbus Channel is located between the south coast of Trinidad and the north coast of Venezuela. It has a maximum depth of less than $55 \mathrm{~m}(30$ fathoms). The Gulf of Paria however, is relatively flat with a maximum depth of approximately $28 \mathrm{~m} \mathrm{(15}$ fathoms). Columbus Bay is relatively shallow with a maximum depth of approximately $5.5 \mathrm{~m}$ (3 fathoms) just beyond Los Gallos headland to the north and Corral Point to the south.

The nearshore wind speed at Columbus Bay averaged $1.24 \mathrm{~ms}^{-1}$ from the east during the period $2004-2008$ (Darsan et al., 2012). There are plunging waves of moderate energy with an average nearshore wave height of $0.30 \mathrm{~m}$ during summer months (May to October) and $0.45 \mathrm{~m}$ during the winter months (November to April) which approach from the north-west (Darsan et al., 2012). Longshore currents generally flow to the south-west (Darsan et al., 2012). Nearshore currents may be in excess of 2 knots to the west, and this may be enhanced by the ebb tide as well as by wind and wave action (Admiralty, 1965).

There is a seasonal river which outflows at the northern region of the bay and a small wetland is located at the central area of the bay (Figure 2). The vegetation at Columbus Bay comprises grasses, shrub, herbaceous swamp and mangrove, fruit and coconut trees (Kenny, 2002). The upper beach is bordered by two coconut plantations; the Constance Estate (to the north) and the St. Quintin Estate (to the south). The land at Columbus Bay is privately owned and is being eroded over centuries possibly by the coupling of wave action and south-west longshore currents (Kenny, 2002).

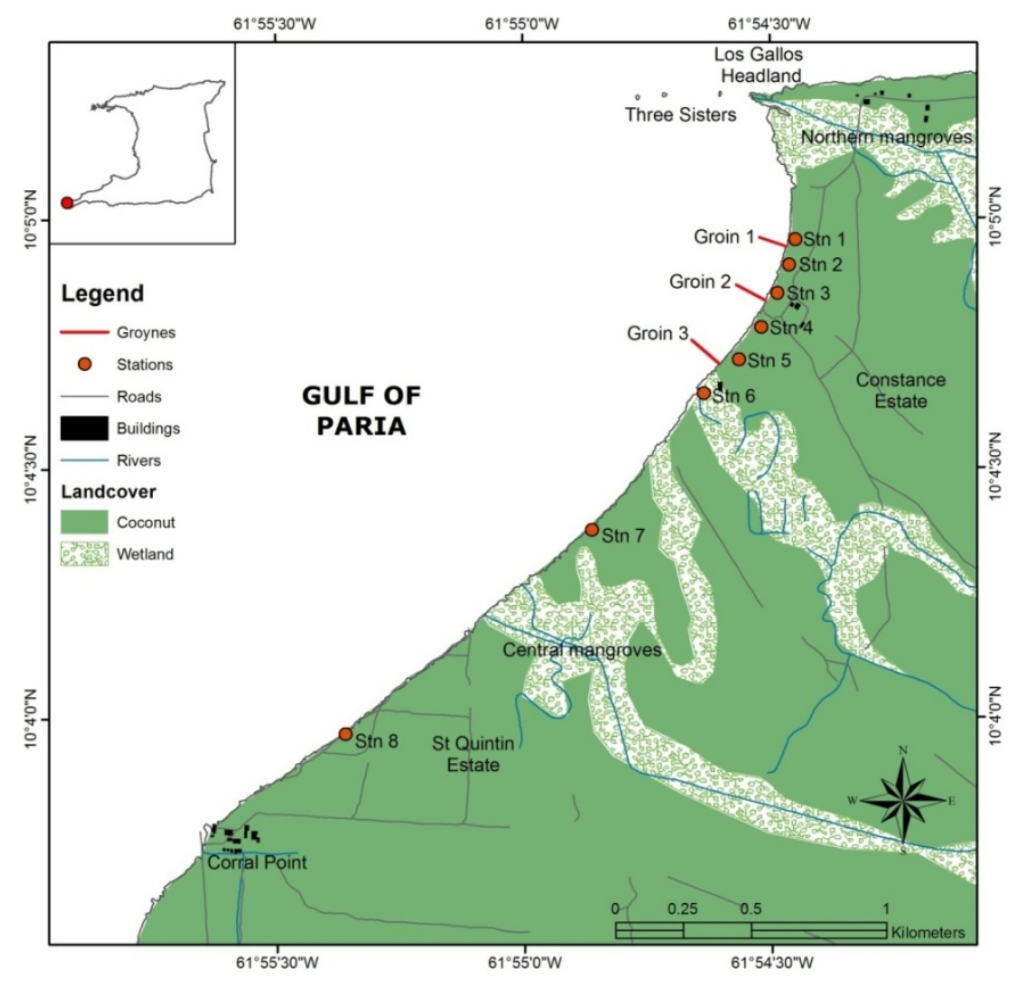

Figure 2. Location of stations and groynes at Columbus Bay

\subsection{Erosion at Columbus Bay}

Columbus Bay has been experiencing coastal erosion for decades and is an ongoing concern. Research conducted in the past (Deane, 1973; Oostdam, 1982; Hudson, 1988; Kenny, 2002; Kanhai, 2009; Darsan et al., 2012) have suggested shoreline stabilization measures from a series of groynes, the reconstruction of the Los 
Gallos headland, to a series of artificial headlands along the bay, although no indication was given to the location and specifications of these structures. The erosion at this area was highlighted by the media in the past with the most recent occurrence being a newspaper article in the Trinidad Express dated the August 26, 2010. The erosion may be as a result of the wave action and susceptible geology of the area (Kanhai, 2009).

In the 1860's, there were six islets together with the pronounced Los Gallos headland. This prominent headland at the Los Gallos Point intercepted some of the oncoming waves into Columbus Bay and dissipated the wave energy. What is left of this headland is now identified as the 'sisters' - three stacks which have withstood the erosive power of the waves thus far (Kenny, 2007). As this headland continues to erode, the wave energy reaching the Bay is expected to increase and possibly accelerate the erosion. The erosion has also affected a small lighthouse (consisting of a small derrick and a flashing beacon) which the sea claimed in the late 1970's (Figure 3) (Kenny, 2007).

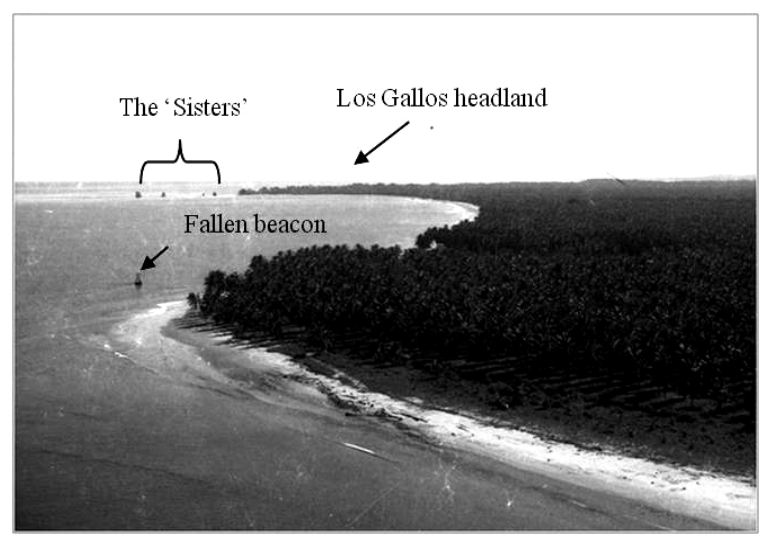

Figure 3. Fallen lighthouse at Columbus Bay (1970’s) (Source: Kenny 2007)

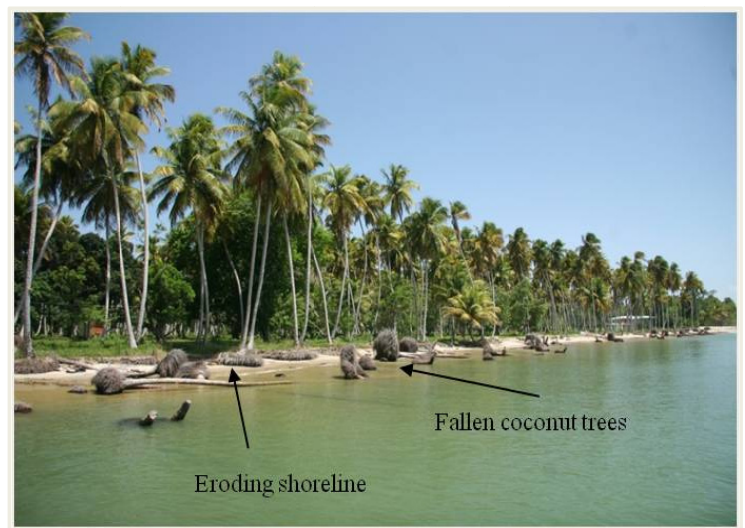

Figure 4. Eroding shoreline along Columbus Bay (2008)

The continual coastal erosion at Columbus Bay claims dozens of coconut trees annually (Figure 4). The loss of these trees and land along the entire bay, results in losses of potential income by the land owner (Table 1). Information obtained from the Constance Estate provides figures on the income surrendered (TTD) by the loss of coconut trees (lifespan of 80 years). The 528 trees lost to erosion over a 30 year period could have potentially generated an income of 950,400 TTD. These same trees would have generated 1,584,000 TTD in additional income over their lifetime had they not been felled by erosion. 
Table 1. Monetary loss at Constance Estate, Columbus Bay (9th November 2010)

\begin{tabular}{ll}
\hline Number of coconut trees lost & Income from coconut trees (TTD) \\
\hline 1 (over 1 yr period) & 31,680 \\
528 (over 30 yr period) & 950,400 \\
528 (over potential 50 yr period) & $1,584,000$ \\
\hline
\end{tabular}

\subsection{Groynes at Columbus Bay}

Erosion in Trinidad is a common phenomenon, and hard engineering structures such as groynes, revetments and seawalls have been suggested as protective strategies (Cambers, 1998a, 1998b). Along Columbus Bay, Trinidad, erosion has been ongoing for many decades and continues to persist (Kenny, 2007). Land is being lost which may be developed recreationally, commercially or residentially. The coastal erosion along Columbus Bay has been documented from different studies since 1973. This loss of land has cost the landowner millions of dollars over the years (Sabastien, 2010). During 2008 three sandbag groynes were installed at the northern region of Columbus Bay to arrest the erosion there (Figures 5 and 6). The permeability, orientation and height of the groyne determine how much sediment is intercepted from the littoral drift. The groynes at Columbus Bay were installed perpendicularly to the shoreline; however, literature suggests that groynes oriented at an acute angle impound more sediment than those oriented at an obtuse angle (Kraus \& Rankin, 2004). Although the landowner stated that the sandbags were impermeable, literature suggests that permeability of sandbags increases with time and wear and tear (USACE, 2002; Griggs, 2004).

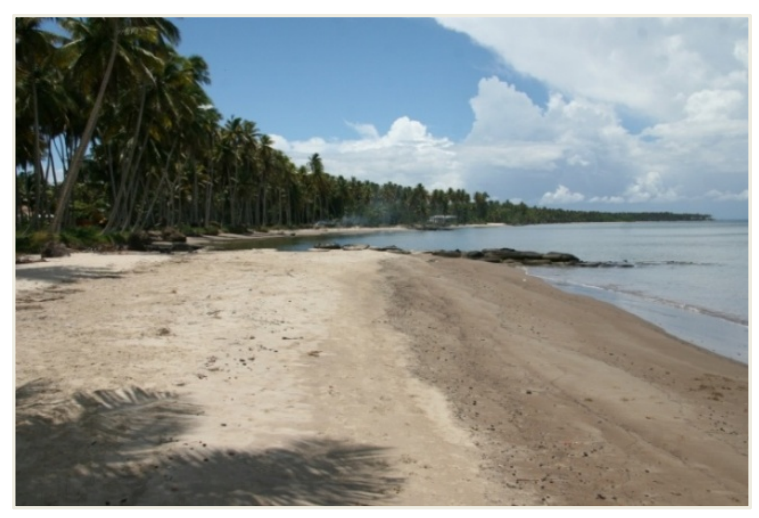

Figure 5. Updrift of Groyne 1, Columbus Bay (2010)

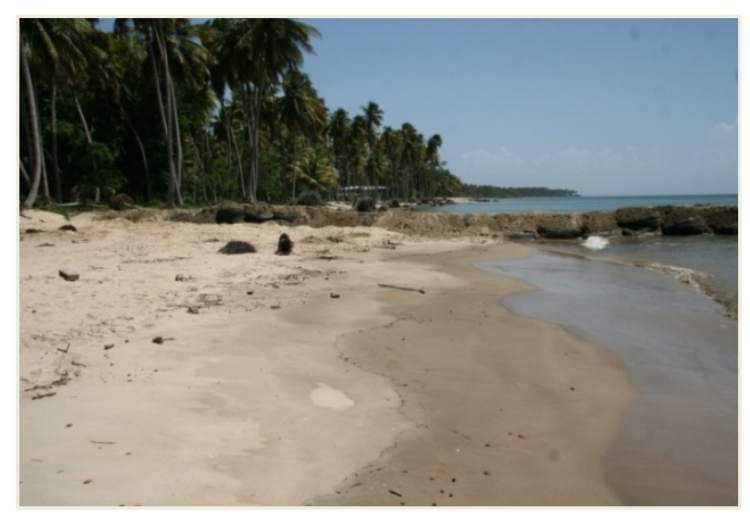

Figure 6. Updrift of Groyne 2, Columbus Bay (2010)

Table 2 indicates the lengths, heights, widths and spacing of the groynes at Columbus Bay after installation in 2008. 
Table 2. Parameters of groynes at Columbus Bay

\begin{tabular}{cccccc}
\hline \multirow{2}{*}{ Structure } & \multirow{2}{*}{ Year } & \multicolumn{4}{c}{ Parameter } \\
\cline { 3 - 6 } & & Length $(\mathrm{m})$ & Width $(\mathrm{m})$ & Height $(\mathrm{m})$ & Spacing $(\mathrm{m})$ \\
\hline Groyne 1 & 2008 & 45 & 2 & 2 & 215 (between groynes 1 and 2) \\
Groyne 2 & 2008 & 50 & 2 & 2 & 285 (between groynes 2 and 3) \\
Groyne 3 & 2008 & 45 & 3 & 3 & N / A \\
\hline
\end{tabular}

\section{Methods}

Beach profiles and littoral data were collected monthly from October 2009 to April 2011 at 8 stations (Figure 2). Sediment samples were also collected at the mid-beach region of each profile transect. A combination of beach profiles, coastal processes, beach width and beach volume data, and a modelled shoreline response from CEDAS will form the basis of the evaluation on the effectiveness of the groynes at Columbus Bay. The effectiveness of the groynes was determined based on the net differences between the baseline (October, 2009) and monthly beach profile measurements together with differences from a Generalized Shoreline change Numerical model (GENESIS) between the initial shoreline (1994 aerial photograph), the reference shoreline (2007 Ikonos Satellite Imagery), the measured shoreline (2011) and the final (modelled) shoreline.

\subsection{Beach Profiles}

Beach profiles were measured using standard surveying techniques. The following pieces of equipment were used; a Sokkia $\mathrm{B}_{2} 0$ automatic survey level, a dome-head tripod, a $100 \mathrm{~m}$ measuring tape, a $7.60 \mathrm{~m}$ survey staff and a Brunton direct pointing compass. Eight benchmarks were constructed along the bay (Figure 1). The elevation used in this research was obtained from the Lands and Surveys Division of the Ministry of Food Production, Land and Marine Resources. The Lands and Surveys benchmark number 507 had a reported elevation of 3.820 feet or $1.164 \mathrm{~m}$ above the Mean Sea Level datum which was established in 1964. The benchmark was located at the base of the bell tower in the church yard at Icacos. This elevation was transferred from the base of the bell tower to the stations at Columbus Bay with the use of a Sokkia Digital Power Level and RAB code staves. The accuracy of the transfers was maintained as transfers were not accepted if the error obtained was greater than $0.020 \mathrm{~m}$ over a distance of $1 \mathrm{~km}$.

Readings were taken from the station and at $4 \mathrm{~m}$ intervals along the profile direction up to a water depth of approximately $1.50 \mathrm{~m}$. If, however, there were notable changes along the profile direction such as the vegetation line, high water mark or a change in gradient such as a scarp or cusp for example, these were recorded. Observations of monthly beach profile changes were collected at the 8 shore-normal beach profile transects situated along the length of Columbus Bay. Monthly surveys were performed from October, 2009 to April, 2011 for each of the eight stations with the exception of station 6 for which a total of nine surveys were obtained. Beach profiles were conducted during a spring low tide so that the maximum profile distance possible could be obtained.

\subsection{Beach Volume}

Beach profiles were used to obtain and compare beach width and volumes across each station. Beach width and beach volume are good indicators of a stable beach (Reeve, Chadwick, \& Fleming, 2004). Beach volume is defined in this paper as the cross sectional area between the permanent benchmark and mean sea level per unit length of beach. Beach volume changes were measured as deviations from the baseline established in October 2009 when each profile was measured. Beach volume was calculated for the monitoring period October 2009 to April 2011. The beach volume was determined using the trapezoid rule in Microsoft Excel 2007 where the area of the beach profile above the elevation datum (MSL) was calculated (Figure 7). The profile area was then multiplied by $1 \mathrm{~m}$ to determine the volume per meter of shoreline, since a beach profile transect is representative of $1 \mathrm{~m}$ width of beach (IMA, 2005). 


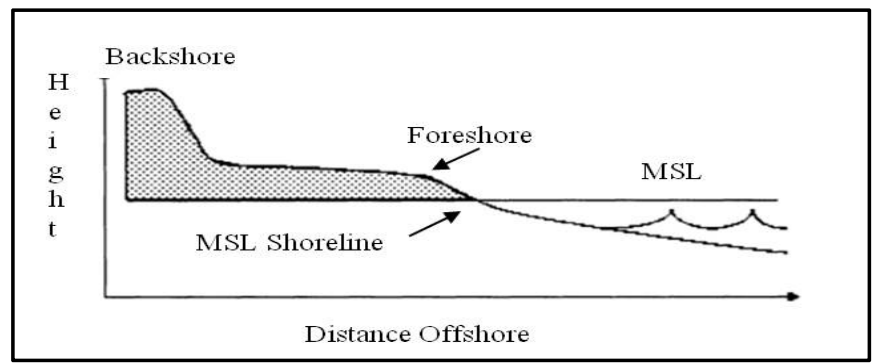

Figure 7. A schematic of a cross shore profile

The horizontal line represents the mean sea level (MSL). The shaded area represents the subaerial volume per meter shoreline. The MSL shoreline is shown as the intersection of MSL with foreshore (Farris \& List, 2007) (Figure 7).

\subsection{Beach Width}

Beach width is defined in this paper as the horizontal distance from the benchmark, seaward to the intercept of the foreshore with mean sea level (Figure 7). Beach width changes were measured as deviations from the baseline established in October 2009, and calculated for the period October 2009 to April 2011.

\subsection{Littoral Fieldwork Observations}

Littoral fieldwork observations were obtained using Schnider (1981) and Goudie et al. (1990), simultaneously with beach profiles. The littoral observations included beach orientation, wave and breaker types, wave heights and directions, wind speed and direction, and longshore current speed and direction. The beach orientation was obtained by standing at the midbeach region of each station location and pointing the Brunton compass to either end of the beach and recording the bearings. These bearings were later converted to cardinal points. The wave height was measured with a $7.60 \mathrm{~m}$ extendable survey staff just behind the breakers and was taken as the height difference between the wave trough and crest. The breaking wave heights were measured in a similar fashion. The wave approach was measured from the shoreline at each station location with a Brunton direct pointing compass which was pointed toward the oncoming waves and the direction recorded. The longshore speed was obtained from a floating object which was thrown into the water seaward of the breaker zone. The distance travelled by the object in 60 seconds was recorded and the current speed was represented as $\mathrm{cms}^{-1}$.

\subsection{Sediment Grain Size}

Sediment samples were obtained monthly from the mid beach region at each of the eight monitoring stations using a hand shovel. Sediment samples were oven dried at $105^{\circ}$ for 24 hours. A known weight of sample (120 g) was sieved at intervals using $1 / 2 \phi$ using an automatic sieve shaker (Octagon digital) and ASTM E11 $20 \mathrm{~cm}$ diameter sieves (mesh no. 5/8 to 230) for 15 minutes. Folk and Ward (1957) graphical computation method was utilized to calculate the statistical parameters of the grain size (mean, standard deviation, skewness and kurtosis). Statistical analysis of the results and graphical analysis of the data were performed using GRADISTAT software (Blott \& Pye, 2001) version 8.0. The mean grain size $\left(\mathrm{D}_{50}\right.$ value $)$ was input into the GENESIS model simulation.

\subsection{Numerical Modelling}

Shoreline modelling was undertaken with the STWAVE and GENESIS components of the CEDAS software. The effectiveness of the groynes at this bay should correspond to their ability to prevent erosion (loss of sediment) or encourage accretion (gain in sediment) by the impoundment of littoral drift at Columbus Bay. Firstly a conceptual model was created with data obtained about the site inclusive of bathymetry, shoreline and coastal processes (such as winds, waves, currents and tides) which were used to produce an image of how the coastal conditions may impact the bay.

\subsubsection{Wave Model}

Offshore wave time series (12 months) obtained from Atlantic LNG Company of Trinidad and Tobago was imported into NEMOS, filtered and then analyzed with WSAV. Following this the data were imported into SPECGEN to simulate the wave model. Outputs were viewed with the WMV module of the CEDAS software. The bathymetry, shoreline and the generated grid were saved as separate files to be used later within GENESIS. STWAVE was selected because this programme allows wave trains to be simulated across bathymetry with parallel contours. One year of wave data (21st February 2009 to 20th February 2010) recorded from a wave 
gauge off the coast at Point Fortin was used. The wave data was filtered and parameters were adjusted in NEMOS, from the USACE computer application package ACES. The adjusted wave data parameters were used as input into the module STWAVE. The STWAVE model parameters configured were wind, wave, water level specifications and input/output file associations were adjusted. The water level used was that of mean sea level (MSL) obtained from the elevations determined by the Land and Surveys Division of the Ministry of Food Production, Land and Marine Resources.

\subsubsection{Shoreline Change Model}

The only available bathymetry (Admiralty, 1965) was imported into the GENESIS software and the points were triangulated, which allowed for the interpolation of depths between points. The shoreline position at Columbus Bay represents the distance from a local coordinate system $(1112600 \mathrm{~N})$, which serves as the baseline (x-axis). The origin of the GENESIS coordinate system was located at the seaward southwest limit of the grid (617162.655 E, $1136312.039 \mathrm{~N})$. The 1994 (initial) and 2007 (reference) shorelines were obtained from aerial photography and Ikonos satellite imagery respectively. The 2011 (measured) shoreline of Columbus Bay was mapped with a differential Trimble ${ }^{\circledR}$ R6 GNSS receiver. Model boundaries for GENESIS were selected at the Los Gallos headland to the north, and approximately $400 \mathrm{~m}$ east of Corral Point to the south. This region of the shoreline was selected as GENESIS computes straighter shorelines (those without indentations or outcrops) with higher accuracy.

The shoreline change model GENESIS was used to simulate the four year period, February 21, 2007 to February 20, 2011. The GENESIS model of Columbus Bay spans a $4200 \mathrm{~m}$ stretch of the Cedros south-west coastline from Corral Point, north-east to Los Gallos Point. This reach of shoreline was modelled with 169 points, equally spaced at $25 \mathrm{~m}$ intervals. The shoreline position was specified at each of the points and was referenced to a longshore baseline. All shoreline positions were referenced with respect to a vertical datum to allow for accurate comparisons of shoreline computed with GENESIS.

The model was calibrated and verified with the use of the Columbus Bay shorelines of 1994 and 2007 respectively to reproduce historical shoreline change and net longshore sediment transport rates in the vicinity. For proper implementation of GENESIS, at least three shorelines were required, two for input into the model for initial conditions (1994 and 2007) and a third for referencing during calibration (2011). This provided for a reasonable length of time among the shoreline data sets in order to properly capture the long-term macro-scale effects of coastal processes in the study area. The four-year period from 21st February 2007 to 20th February 2011 was selected as the model calibration interval, to determine how the calculated shoreline agrees with the measured shoreline of 2011. Model errors which may have occurred may have been as a result of coastal processes not being included in the GENESIS code, such as the cross-shore movement of sand. Coupled with this error was the limitation of available wave data and the assumption that the wave climate over the four years did not change.

\section{Results and Discussion}

\subsection{Groyne Parameters}

The groynes have all exhibited reductions in height which may have been due to settling or spreading of the sandbags on the sea floor. These height reductions may have allowed more sediment to pass over the top of the groyne when submerged. In addition to permeability, height and orientation, length and spacing also influence sediment impoundment at or between groynes (Table 3). 
Table 3. Parameters of groynes at Columbus Bay

\begin{tabular}{cccccc}
\hline \multirow{2}{*}{ Structure } & Year & \multicolumn{5}{c}{ Parameter } \\
\cline { 3 - 6 } & & Length $(\mathrm{m})$ & Width $(\mathrm{m})$ & Height $(\mathrm{m})$ & Spacing $(\mathrm{m})$ \\
\hline \multirow{2}{*}{ Groyne 1 } & 2008 & 45 & 2 & 2 & $215 \mathrm{~m}$ (between groynes 1 and 2) \\
& 2011 & 45 & $\mathbf{3}$ & $\mathbf{1 . 7}$ & 285 m (between groynes 2 and 3) \\
\hline \multirow{2}{*}{ Groyne 2 } & 2008 & 50 & 2 & 2 & $\mathrm{~N} / \mathrm{A}$ \\
& 2011 & 50 & $\mathbf{3}$ & $\mathbf{1 . 7}$ & $\mathbf{2}$ \\
\hline \multirow{2}{*}{ Groyne 3 } & 2008 & 45 & 3 & $\mathbf{2 . 6}$ & \\
& 2011 & 45 & $\mathbf{4}$ & & \\
\hline
\end{tabular}

Table 3 indicates that widths of the groynes at Columbus Bay in 2008 have all increased when measured in 2011. The table also indicates a reduction in height of all groynes though the lengths and spacing have remained unchanged between 2008 and 2011. Studies have shown that a relationship exists between the length and spacing of groynes for sufficient sediment impoundment (Kraus \& Rankin, 2004). (USACE, 2002) suggests groyne spacing should be between 2 to 3 times that of groyne length. Table 4 provides information for current groyne length and spacing together with theoretical (suggested) spacing for 3 times the groyne length at Columbus Bay.

Table 4. Groyne lengths and spacing for Columbus Bay

\begin{tabular}{cccccc}
\hline Groyne & $\begin{array}{c}\text { Groyne } \\
\text { Length }(\mathrm{m})\end{array}$ & $\begin{array}{c}\text { Groyne } \\
\text { Spacing }(\mathrm{m})\end{array}$ & $\begin{array}{c}\text { Suggested spacing } \\
\text { from literature }(\mathrm{m})\end{array}$ & Difference (m) & $\begin{array}{c}\text { Percentage } \\
\text { Difference (\%) }\end{array}$ \\
\hline 1 & 45 & 215 & 135 & 80 & 59.26 \\
2 & 50 & 285 & 150 & 135 & 90.00 \\
3 & 45 & N/A & 135 & N/A & N/A \\
\hline
\end{tabular}

Table 4 indicates that the present spacing between groynes 1 and 2 was almost $60 \%$ more than that suggested by the literature. Table 4 also indicates that the spacing between groynes 2 and 3 was almost double the suggested distance from the literature for a $50 \mathrm{~m}$ groyne. (USACE, 2002) suggests that terminal groynes should be progressively tapered to a value of $6 \%$ from groyne tip to groyne tip. Tapering of the groynes reduces the erosive impact in the lee of the groynes to a minimum (USACE, 2002). This data suggests that suggested guidelines were not adhered to. The tapered groyne should have been $47 \mathrm{~m}$ in length and spaced $141 \mathrm{~m}$ from groyne 3 .

\subsection{Littoral Processes}

The approach of the wind was generally from the east and has relatively uniform average wind speeds with the weakest wind $\left(0.78 \mathrm{~ms}^{-1}\right)$ experienced at Station 4 . Breaking waves impact all stations along Columbus Bay shoreline from the northwest with the exception of station 8 which was impacted from the north. Breaking wave heights generally increased from $0.27 \mathrm{~m}$ at station 1 in the north to $0.38 \mathrm{~m}$ at station 8 toward the southern limit of the bay. The mean breaking wave period is generally constant with the shortest periods (7.91 s and $7.61 \mathrm{~s})$ observed at stations 3 and 4 respectively. The mean longshore current speeds are faster at both ends of the bay and flows generally to the south-west. The central stations 3 to 5 have the slowest current speeds and a general north-east direction (Table 5). These north-east currents were probably generated as waves reflected from the $2^{\text {nd }}$ and $3^{\text {rd }}$ groynes at stations 3 and 5 respectively. 
Table 5. Littoral processes data for Columbus Bay for the period October 2009 - April 2011

\begin{tabular}{|c|c|c|c|c|c|c|c|c|c|c|c|}
\hline \multirow{3}{*}{ Station } & \multirow{2}{*}{\multicolumn{2}{|c|}{$\begin{array}{r}\text { Wind } \\
\text { Speed }\left(\mathrm{ms}^{-1}\right)\end{array}$}} & \multirow{3}{*}{ Dir } & \multicolumn{5}{|c|}{ Breakers } & \multirow{2}{*}{\multicolumn{2}{|c|}{$\begin{array}{l}\text { Longshore Curre } \\
\text { Speed }\left(\mathrm{cms}^{-1}\right)\end{array}$}} & \multirow{3}{*}{$\begin{array}{l}\text { Dir } \\
\text { Dir }\end{array}$} \\
\hline & & & & \multicolumn{2}{|c|}{ Breaker Height (m) } & \multirow{2}{*}{ Dir } & \multicolumn{2}{|c|}{ Breaker Period (s) } & & & \\
\hline & Mean & Range & & Mean & Range & & Mean & Range & Mean & Range & \\
\hline 1 & 1.15 & $0.00-2.80$ & $\mathrm{E}$ & 0.27 & $0.10-0.50$ & NW & 8.28 & $6.70-10.70$ & 13.39 & $1.93-33.83$ & SSW \\
\hline 2 & 1.35 & $0.00-3.90$ & E & 0.27 & $0.15-0.50$ & NW & 8.23 & $6.30-11.10$ & 10.07 & $2.90-23.80$ & SW \\
\hline 3 & 1.48 & $0.00-3.30$ & $\mathrm{E}$ & 0.29 & $0.10-0.50$ & NW & 7.91 & $6.40-10.30$ & 9.03 & $0.97-34.13$ & $\mathrm{NE}$ \\
\hline 4 & 0.78 & $0.00-1.60$ & $\mathrm{SE}$ & 0.33 & $0.20-0.70$ & NW & 7.61 & $5.30-10.10$ & 7.07 & $0.97-23.20$ & SW \\
\hline 5 & 1.33 & $0.30-2.70$ & ESE & 0.36 & $0.10-0.80$ & NW & 8.39 & $6.90-11.40$ & 8.57 & $1.07-18.67$ & $\mathrm{NE}$ \\
\hline 6 & 0.90 & $0.00-1.80$ & $\mathrm{E}$ & 0.29 & $0.20-0.50$ & NW & 8.51 & $6.80-10.10$ & 12.94 & $1.93-29.87$ & SW \\
\hline 7 & 1.40 & $0.00-4.00$ & E & 0.34 & $0.20-0.75$ & NW & 8.55 & $7.10-12.20$ & 10.23 & $2.90-21.33$ & SW \\
\hline 8 & 1.51 & $0.00-4.50$ & E & 0.38 & $0.20-0.60$ & $\mathrm{~N}$ & 8.33 & $6.70-11.00$ & 13.59 & $3.20-27.20$ & WSW \\
\hline
\end{tabular}

Note: "Dir" - Direction.

The general wave approach to Columbus bay was from the north-west (Figure 8). The general flow of longshore current at Columbus bay was to the south-west (Figure 9).

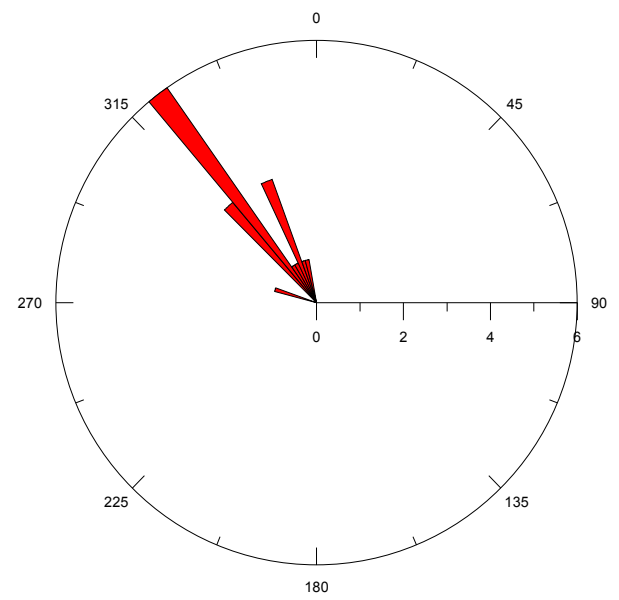

Figure 8. Combined rose plot of wave approach to Columbus bay (all stations)

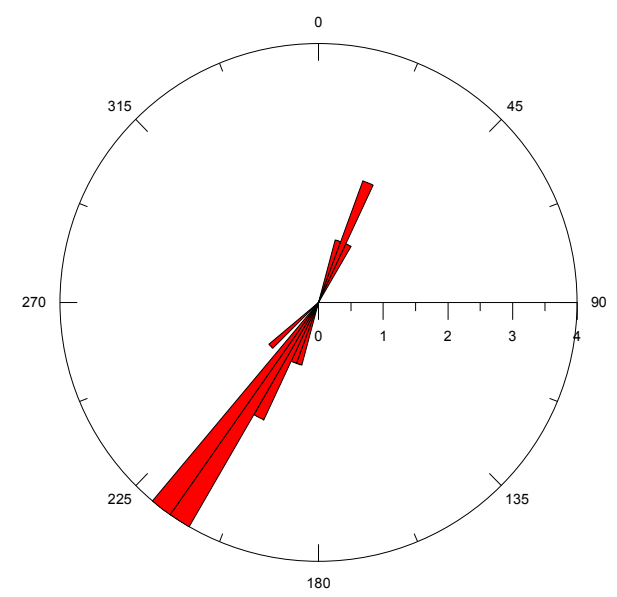

Figure 9. Combined longshore current plot at Columbus bay (all stations) 
Columbus Bay is exposed to various coastal processes. There are swell waves from the north (through the Dragon's Mouth) and the Guiana Current flows from the east (through the Serpent's Mouth) at the southern end of the bay. Research has shown that a clockwise gyre occurs within the Gulf of Paria and influences a south westerly longshore current at Columbus Bay (Gopaul \& Wolf, 1995). This longshore current impacts the bay negatively by transporting the unconsolidated sediment away from the bay (Kenny, 2007). This results in loss of land at the Constance and St. Quintin estates.

\subsection{Beach Profiles}

At station 1, located just updrift of groyne 1, there was a continuous increase in the berm elevation from October 2009 to April 2011 (Figure 10). The profile recorded maximum depositional levels in January 2011, which may have been linked to a high energy event (such as swell waves). During this period, there were a few low pressure systems in the North Atlantic which were potential swell generating systems. Data for beach width and volume show a similar trend over this time period. The profile however returned to its normal sand levels by April 2011. Overall there has been a slight increase in the sediment volume at this station, with beach width displaying a negative trend line (Figure 11). The observed trend for beach volume was accretion of $0.80 \mathrm{~m}^{3} / \mathrm{m} / \mathrm{yr}$ over the period October 2009 to April 2011.

The beach profiles at station 2 (just downdrift of groyne 1) illustrated a distinct scarp in October 2009 at the start of the data collection period. This scarp however, prograded by $8 \mathrm{~m}$ in April 2011 as accretion produced a gentler slope. A similar accretionary event occurred in January 2011 as observed with station 1, which was later reduced by April 2011 (Figure 10). The trend observed at station 2 was accretion of $4.78 \mathrm{~m} / 3 / \mathrm{m} / \mathrm{yr}$ over the study period (Figure 11). The increases to beach width at this station coincided with a loss in beach width at Station 1 for the same period. This is unusual as station 2 being located in the shadow zone of groyne 1, would have restricted sediment supply, which should encourage erosion. A possible explanation for the observed accretion at this station is the length of the groyne $(50 \mathrm{~m}$ ), and distance of the station from the groyne (approx $150 \mathrm{~m}$ ) which would not have been effective in starving the downdrift area of sediment.

Beach profiles at station 3, located updrift of groyne 2, illustrated a scarp in January 2010 which developed into a berm up to the end of data collection in April 2011 (Figure 10). This occurred as sediment was impounded by the interception of the south-westerly littoral drift by groyne 2 . There was also an unusual increase in sediment on January 2011 along the subaqueous region of the profile (Figure 10) as at the first 2 stations. The accretionary trend for beach width occurred at an average rate of $2.15 \mathrm{~m} / \mathrm{yr}$ over the study period. The trends observed for beach volume increased with an average increase in sediment of $0.71 \mathrm{~m}^{3} / \mathrm{m} / \mathrm{yr}$ over the period October 2009 to April 2011 (Figure 11).

Station 4 was located just downdrift of groyne 2. There were distinct scarps in October 2009 and April 2011 (Figure 10). The beach profile of October 2009 indicates the lowest sediment level in the subaqueous region of the transect. Subsequent beach profiles illustrate little movement from the equilibrium transect with the greatest sediment elevation in the surfzone occurring in January 2011. The trend lines observed for beach width and volume increased over the study period. Volume increased at a rate of $0.55 \mathrm{~m}^{3} / \mathrm{m} / \mathrm{yr}$ over the period October 2009 to April 2011 (Figure 11).

The beach profiles obtained at station 5 (located updrift of groyne 3) show very little dynamism over the study period, October 2009 to April 2011. There was little accumulation of sediment over this time period; however, the profile of January 2011 illustrated the greatest deposition of sediment in the surf zone (Figure 10). An accretionary trend was observed in beach width at an average rate of $1.20 \mathrm{~m} / \mathrm{yr}$ over the study period. The trend for beach volume increased slightly at a rate of $0.22 \mathrm{~m}^{3} / \mathrm{m} / \mathrm{yr}$ over the period October 2009 to April 2011 (Figure $11)$. 

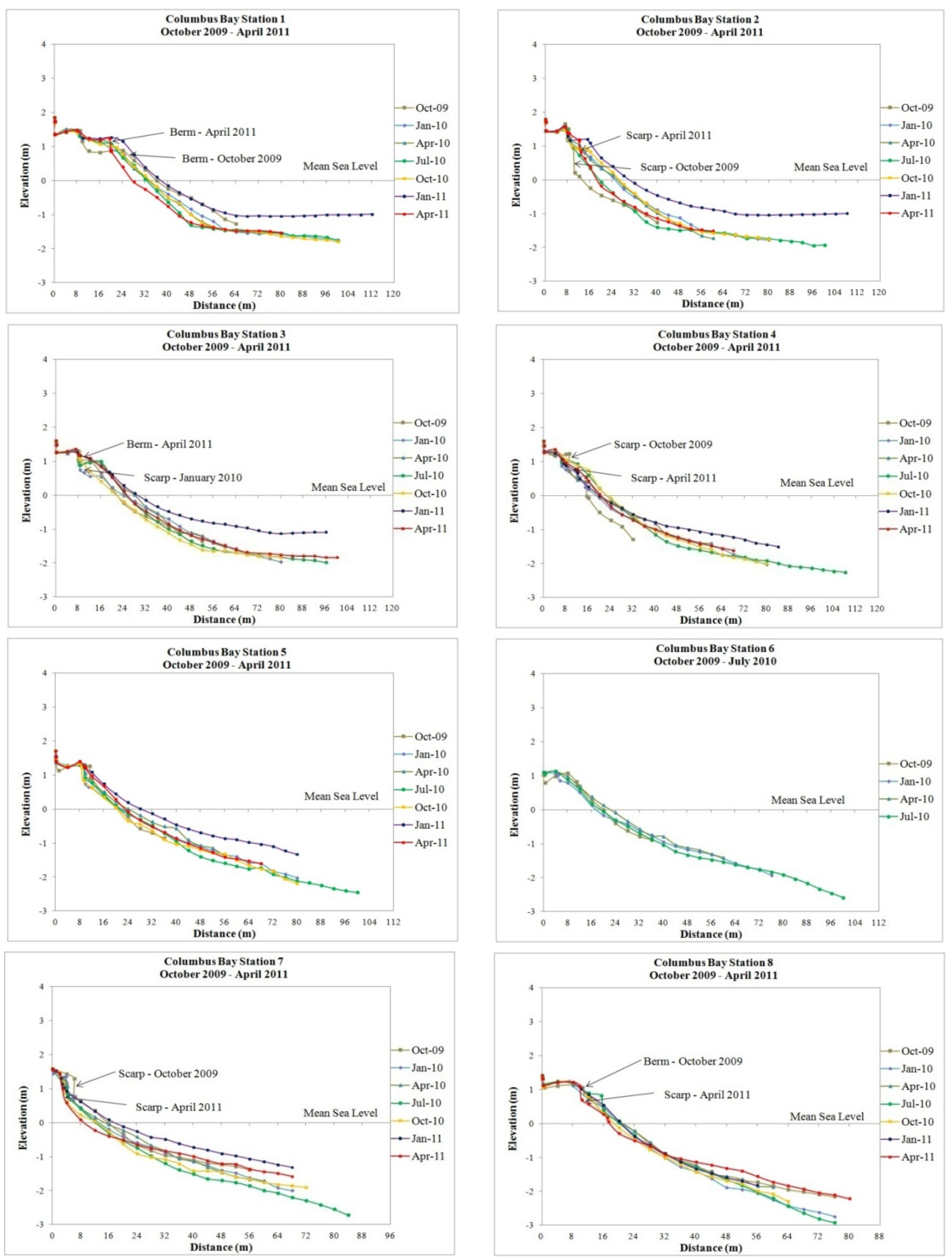

Figure 10. Beach profiles of all stations at Columbus Bay (October 2009 to April 2011)

Station 6 is located in the shadow zone (downdrift) of groyne 3 and illustrates a generally uniform beach profile with not much dynamism occurring over the period October 2009 to July 2010 (Figure 10). This station was destroyed in the subsequent month by a swollen river in the mangrove region backshore. There was a slight increase in beach width at a rate of $0.98 \mathrm{~m} / \mathrm{yr}$ over the period October 2009 to July 2010. There was almost no net change in beach volume for the same time period (Figure 11). 
Station 7 was located at the central region of Columbus bay (downdrift of the groyne field in the northern region of the bay). At this station, data was available before groyne construction and therefore could be used to evaluate the pre and post groyne construction phases. The beach profiles illustrate a distinct scarp in October 2009 which retreats landward until April 2011 (Figure 10). Over the period January 2000 to April 2008 the beach at this station generally accreted, as evidenced by the positive increases to beach width and volume. Subsequent to the installation of the groynes in October 2008, both beach width and volume show a negative trend as sediment was being restricted by the groynes updrift. Coastline retreat was observed after groyne construction at a rate of $2.87 \mathrm{~m} / \mathrm{yr}$ (Figure 11).

Station 8 was located at the southern region of Columbus Bay. Beach profiles illustrate erosion as a small berm in October 2009 developed into a scarp by April 2011 (Figure 10). The elevated sediment levels recorded at other stations were not observed at this station in January 2011. Coastline retreat was observed at station 8 which occurred at a rate of $-0.85 \mathrm{~m} / \mathrm{yr}$ over the study period. There also were erosional trends for both beach width and volume, with the latter occurring at a rate of $-0.11 \mathrm{~m}^{3} / \mathrm{m} / \mathrm{yr}$ over the study period (Figure 11).

Beach profile measurements, beach width and beach volume assessments for Stations 1 to 6 indicate sediment impoundment despite improper practices during the installation of the groynes at Columbus Bay such as; order of groyne construction and spacing between groynes. The groynes may have caused sediment to accumulate within the groyne field resulting in the formation of berms. Stations 1, 2, 3, 4, 5 and 6 all exhibited pronounced berms as a result of the interception of littoral drift at these regions of the bay together with the corresponding reduction of wave energy in the shadow region of the groynes. The presence of the berms indicates accretion which suggests that the groynes are effective. A similar effect was observed in the Netherlands by Pilarczyk and Zeidler (1996) where accretion occurred between groynes with the formation of berms. Stations 7 and 8 were outside of the groyne field and experienced reductions in beach volumes evidenced by pronounced scarps. 

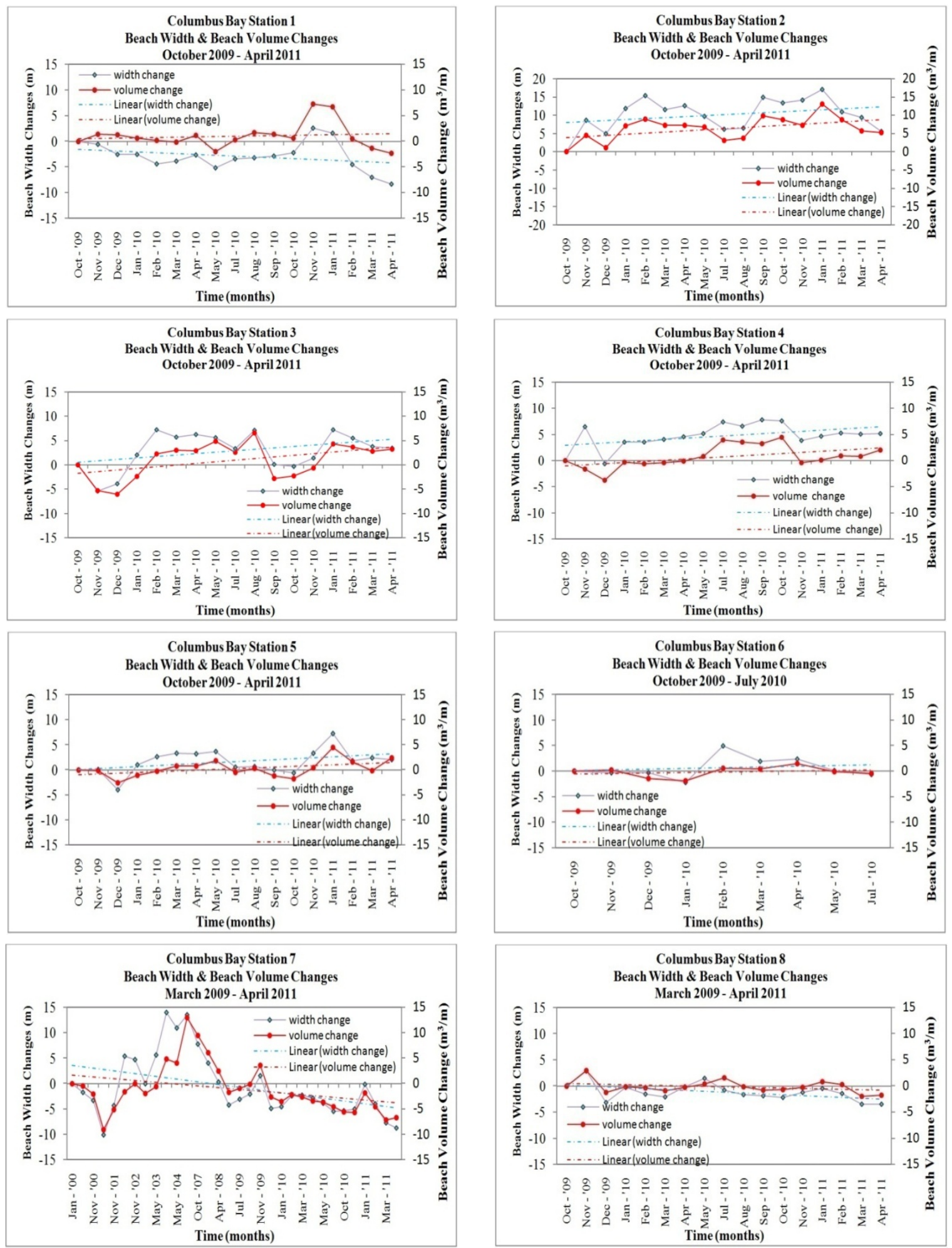

Figure 11. Beach width and volume changes for all stations at Columbus Bay (October 2009 to April 2011)

There have been generally positive trends in beach width and beach volume for stations 1 to 6 (adjacent to the groyne field) over the period October 2009 to April 2011. However, a negative trend is observed in both beach width and beach volume for Stations 7 and 8 located downdrift of the groyne field. Stations 1,7 and 8 experienced negative changes in beach widths, with Station 7 being most negatively affected $(-2.87 \mathrm{~m})$. Stations $2,3,4,5$ and 6 experienced positive changes to beach width, with station 2 experiencing the most accretion (7.60 $\mathrm{m}$ ) over the study period (Figure 12). Stations 1, 2, 3, 4 and 5 all experienced positive changes in beach volumes 
with station 2 gaining the most sediment $\left(4.78 \mathrm{~m}^{3} \mathrm{~m}\right)$ over the study period. Stations 6 and 8 showed no appreciable changes in beach volume while Station 7 was most impacted $\left(-2.35 \mathrm{~m}^{3} \mathrm{~m}\right)$ (Figure 12).

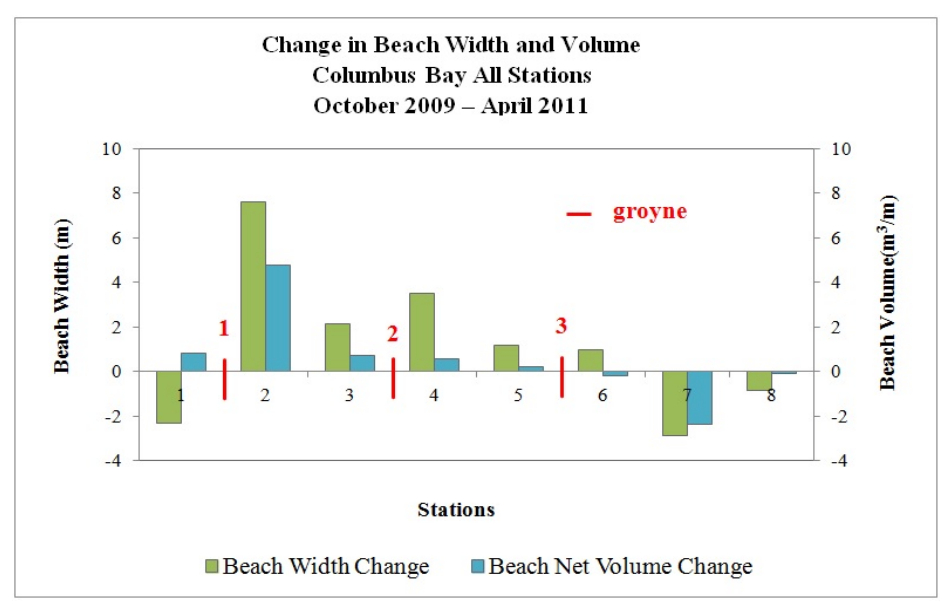

Figure 12. Changes in beach widths and volumes for all station at Columbus Bay (October 2009 to April 2011)

\subsection{Sediment}

The mid-beach sediment comprised a mean grain size $\left(\mathrm{D}_{50}\right.$ value) of $0.20 \mathrm{~mm}$ along the bay (Table 6). This information was used as an input for the GENESIS module of the CEDAS software which calculates a mean beach profile from (Bruun 1952). This calculated profile generates a theoretical depth of closure $\left(D_{C}\right)$ beyond which there is no sediment transport. This calculation determines the volume of sediment transported along the bay.

Table 6. Mid-beach sediment grain size for Columbus Bay 2010

\begin{tabular}{cc}
\hline Station & Grain Size $(\mathrm{mm})$ \\
\hline 1 & 0.21 \\
2 & 0.19 \\
3 & 0.20 \\
4 & 0.19 \\
5 & 0.20 \\
6 & 0.19 \\
7 & 0.21 \\
8 & 0.20 \\
\hline
\end{tabular}

\subsection{Numerical Modelling Output}

\subsubsection{SPECGEN}

The largest spectral output occurred among short period waves with wave periods equal to or less than 6 seconds approaching from the north-west (Figure 13). The numerical model SPECGEN computed various permutations from the 12 months wave data set and calculated that the greatest amount of wave energy occurred at the lowest frequency, north-east of the bay. 


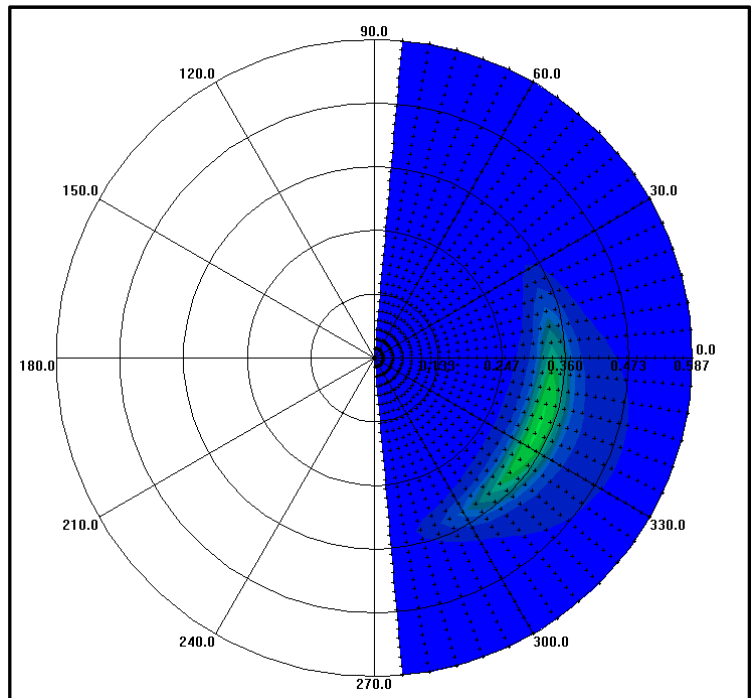

Figure 13. Spectral Wave Output

H_5, Theta_-22.5, T_2.5s

\subsubsection{Wave Model Visualization (WMV) Outputs}

When the output from SPECGEN was input into the Wave Module Visualization (WMV) programme of the CEDAS software, WMV illustrated that the general wave approach was from the north north-west in the offshore region. As the waves approach the bay, there are effects of refraction as the direction of approach changes to north-west. At the southern section of the bay, the wave approach changes to west north-west (Figure 14). This dominant wave approach is responsible for setting up of the south-westerly directed longshore currents that operate in the bay. These results suggest that the majority of sediment at Columbus Bay is transported by short period waves to the south-west.

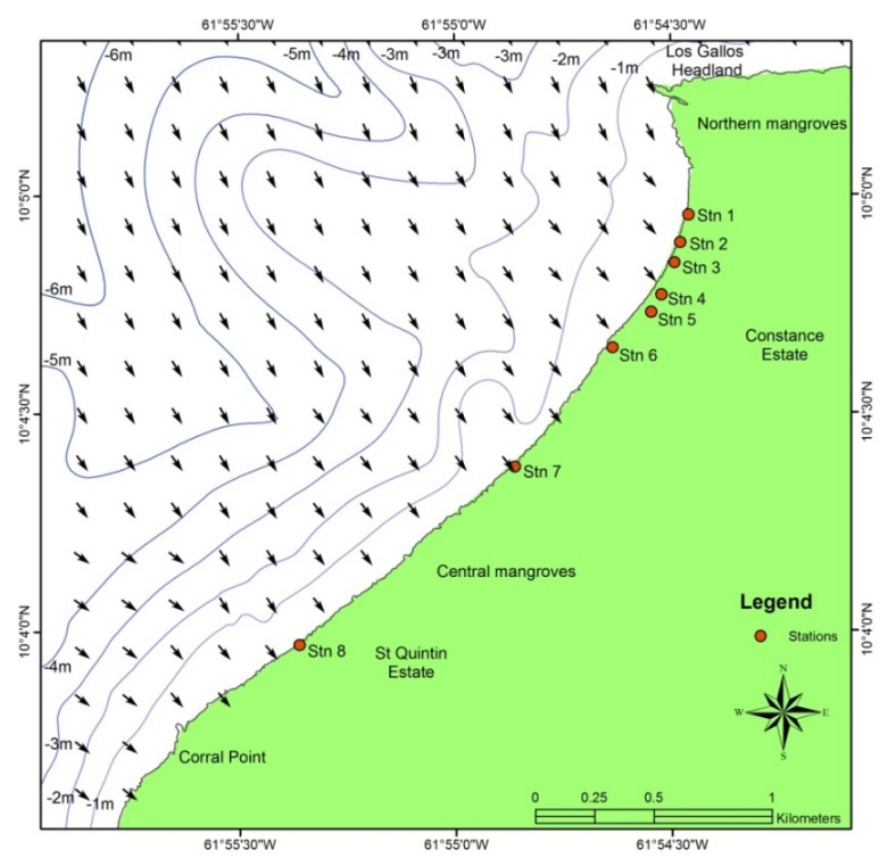

Figure 14. Wave model approach at Columbus Bay

\subsubsection{Sediment Transport}

The volume of sediment transport with and without groynes for the period 2007 to 2011 are illustrated in Tables 
7-8 and Figures 15-16. The alongshore flow of water generally has some influence on the sediment transported along a bay. The outputs from the GENESIS software suggest that approximately $13,548.80 \mathrm{~m}^{3}$ of sediment (Table 7; Figure 15) was transported annually from 2007 to 2011 (without groynes) and approximately 10,370.54 $\mathrm{m}^{3}$ of sediment was transported annually from 2007 to 2011, with groynes installed (Table 8; Figure 16). This reduction of sediment transported suggests that the groynes intercepted some of the littoral transport at Columbus Bay. The calculated sediment transport was similar across the annual time periods 2007-2011, and as such, only one epoch 2007-2008 is presented in Figures 15 and 16.

Table 7. Longshore sediment transport $\left(\mathrm{m}^{3}\right)$ without groynes 2007-2011

\begin{tabular}{lllll}
\hline Time Period & Gross & Net & Left & Right \\
\hline $2007-2008$ & 13861.00 & -12930.81 & -13395.88 & 465.14 \\
$2008-2009$ & 13616.94 & -12778.90 & -13197.89 & 419.02 \\
$2009-2010$ & 13428.90 & -12598.86 & -13013.88 & 415.07 \\
$2010-2011$ & 13288.37 & -12466.50 & -12877.45 & 410.95 \\
Average & 13548.80 & -12693.77 & -13121.28 & 427.54 \\
Standard Deviation & 247.87 & 203.38 & 225.29 & 25.28 \\
\hline
\end{tabular}

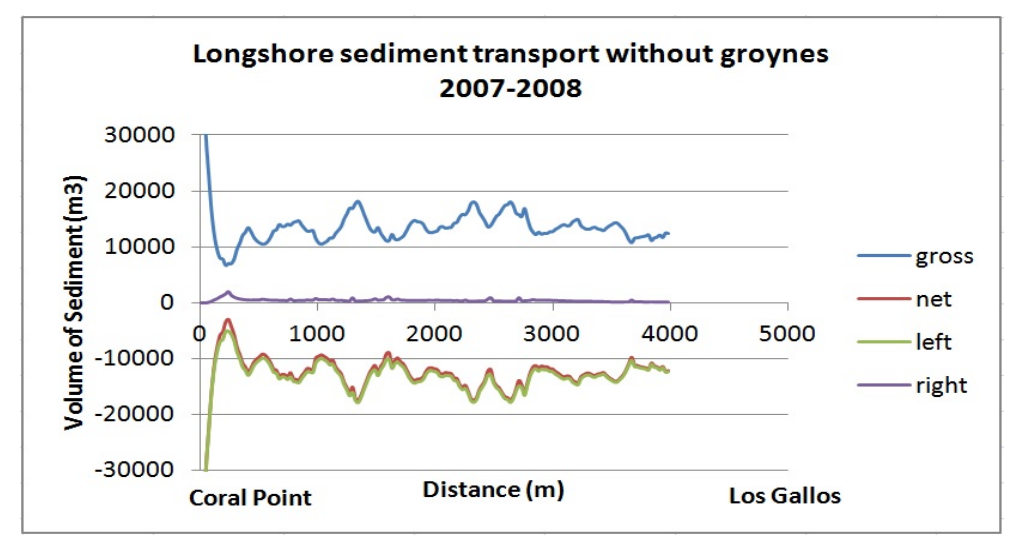

Figure 15. Longshore sediment transport at Columbus Bay without groynes 2007-2008

Gross $=$ total sediment transported; Net $=$ the difference between the left and right; Left $=$ transport to the south-west; and right $=$ transport to the north-east.

Table 8. Longshore sediment transport $\left(\mathrm{m}^{3}\right)$ with the current groynes 2007-2011

\begin{tabular}{lllll}
\hline Time Period & Gross & Net & Left & Right \\
\hline $2007-2008$ & 11219.39 & -9737.88 & -10478.65 & 740.78 \\
$2008-2009$ & 10382.01 & -8537.21 & -9459.57 & 922.43 \\
$2009-2010$ & 10057.52 & -8225.92 & -9141.76 & 915.76 \\
$2010-2011$ & 9823.24 & -8054.59 & -8938.87 & 884.32 \\
Average & 10370.54 & -8638.90 & -9504.71 & 865.82 \\
Standard Deviation & 610.52 & 759.40 & 683.74 & 85.00 \\
\hline
\end{tabular}




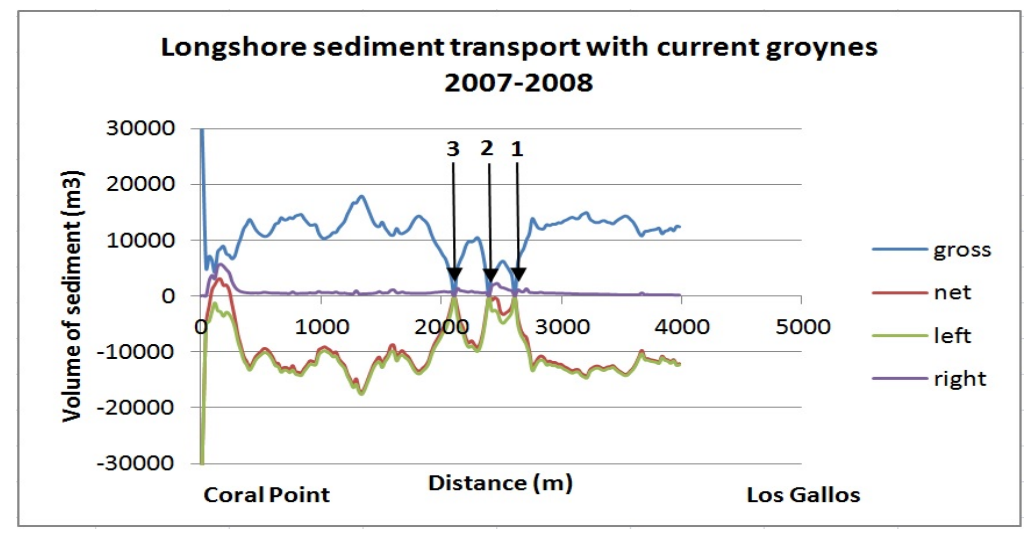

Figure 16. Longshore sediment transport at Columbus Bay with the current groynes 2007-2008

Gross = total sediment transported; Net $=$ the difference between the left and right; Left $=$ transport to the south-west; and right $=$ transport to the north-east.

The calculated volumetric change by GENESIS was $28,000 \mathrm{~m}^{3} / \mathrm{yr}$ without groynes and $7,425 \mathrm{~m}^{3} / \mathrm{yr}$ with groynes over the four year period. These results were greater than the sediment volumes as determined by Deane (1973) of $3,400 \mathrm{~m}^{3} / \mathrm{yr}$ and Kanhai (2009) of $0.0031 \mathrm{~m}^{3} / \mathrm{yr}$. However, the sediment volume of $50,000 \mathrm{~m}^{3} / \mathrm{yr}$ as determined by Oostdam (1982) was much greater than the GENESIS calculation without groynes by almost $200 \%$. The reduced volumetric change as determined by GENESIS with the groynes installed suggests the positive effect the groynes had on the northern region of the bay. More sediment was transported between groynes 2 and 3 than between groynes 1 and 2 for the period 2007 to 2011 (Figure 16).

\subsubsection{Shoreline Change Plots}

Outputs from the GENESIS model of the CEDAS software show the initial, final (modelled) and measured shoreline comparisons for Columbus Bay, with and without groynes (Figure 17).

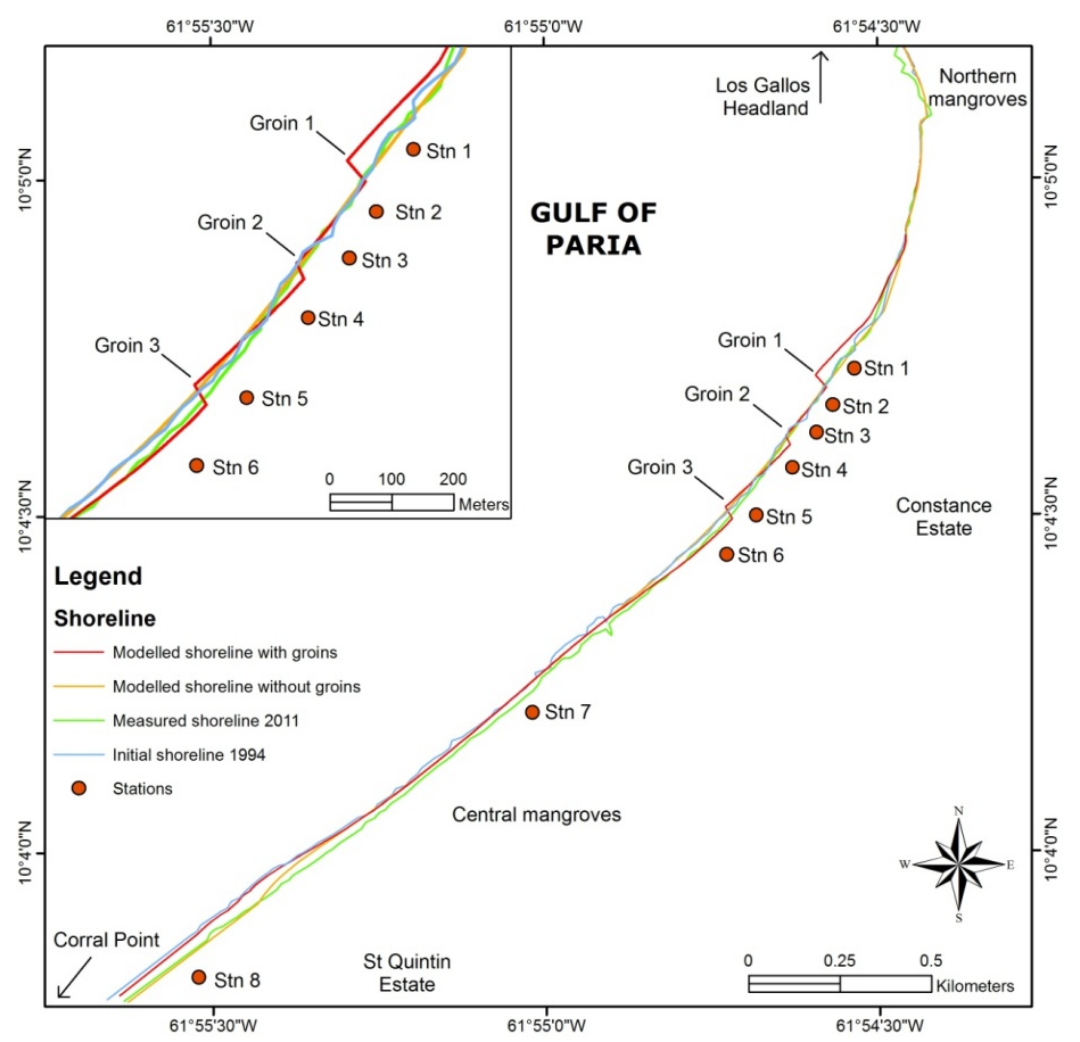

Figure 17. Initial, modelled and measured shoreline comparison for Columbus Bay 
The modelled shoreline without groynes is located between the initial and measured shorelines. The calibration / verification error was calculated as $20.50 \%$ over the four year period 2007-2011 (Figure 17). The GENESIS shoreline with groynes installed also show that the modelled shoreline is generally located between the initial and measured shorelines, except in the area of the groyne field (Figure 17). The calibration/verification error was calculated as $22.44 \%$ over the four year period.

Areas of accretion and erosion were located within or adjacent to the groyne field. The impounding of sediment was most visible in the updrift of the groynes, and was responsible for modifying the shape of the coastline in those areas (Figure 18). An increase in sediment impounding was also observed with the groynes in a southerly direction along the bay; with more sediment being impounded between groynes 2 and 3 than between groynes 1 and 2 .

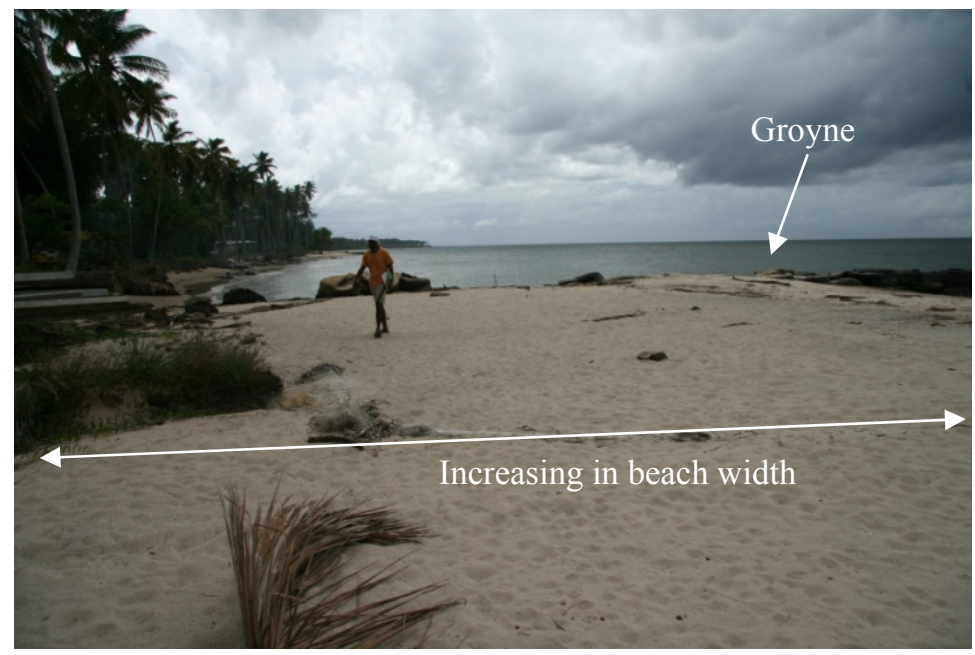

Figure 18. Visible sediment impounding updrift of groyne 2 at station 3 , modifying the shape of the coastline (25th September, 2009)

The GENESIS shoreline output indicated that the final or calculated shoreline was in reasonable agreement with the measured shoreline of 2011 to an accuracy of $79.50 \%$ (Figure 17). Without the groynes, the trend of erosion would have continued at Stations 2, 4, 7 and 8. However, with the groynes, GENESIS calculated accretion at Stations 1, 2, 3 and 5 to an accuracy of $77.60 \%$ (Figure 17). This accretion was confirmed with the beach profiles, beach widths and beach volumes at the respective stations. This accretion suggests that the groynes though not properly engineered, are effective in reducing or arresting erosion in the areas of their installation, along Columbus Bay.

\section{Conclusion}

The beach profiles indicated that five (5) stations experienced net positive change in beach width (within the groyne field) while three (3) stations experienced net negative changes in beach widths. Two of these three stations were outside of the groyne field. The profiles also indicated that the five (5) stations located within the groyne field, experienced net positive changes in beach volume. Three stations showed negative changes in beach volume, however two of these were outside of the groyne field. Results are generally in agreement with literature cited whereby the groyne field at Columbus Bay did not necessarily mitigate the causes of the erosion, but only the effects within the groyne field area. The continued erosion experienced outside of the groyne field (particularly downdrift) at sites 7 and 8 may be attributed to the make-shift groynes that impede sediment transport.

The GENESIS model illustrated continued erosion along Columbus Bay if no groynes were installed. Within the groyne field however, accretion was occurring, with erosion continuing just downdrift of the groyne field. Based on the results obtained from beach profiles and the numerical model GENESIS, the groynes installed at Columbus Bay are effective in reducing erosion at the northern region of Columbus Bay, although their installation did not appear to follow guidelines provided by (USACE, 2002).

While this research was the first attempt to numerically model the coastline changes and the effectiveness of the sandbag groynes at Columbus Bay, it is by no means complete and should form the basis for future research. 
Erosion at Columbus Bay continues to be a serious problem, and while this research has shown the effectiveness of the installed groynes, international standards should be adhered to in the construction of these engineering solutions. The GENESIS model as with all models have assumptions which may not accurately represent the ambient environment being modelled. However, the agreement between the modelled and measured data is a good indication of the usefulness of the model created.

\section{References}

Basco, D. R., \& Pope, J. (2004). Groin Functional Design Guidance from the Coastal Engineering Manual. Journal of Coastal Research, Special Issue(33), 121-130.

Black, K. (2001). Artificial Surfing Reefs for Erosion Control and Amenity: Theory and Application. Journal of Coastal Research, Special Issue(34), 1-14.

Blott, S. J., \& Pye, K. (2001). GRADISTAT: a grain size distribution and statistics package for the analysis of unconsolidated sediment. Earth Surface Processes and Landforms, 26(11), 1237-1248. http://dx.doi.org/10.1002/esp.261

Bruun, P. (1952). Measures against erosion at groins and jetties. Proceedings of the 3rd International Conference of Coastal Engineering. American Society of Civil Engineers. NY. Cambridge, MA, USA.

Cambers, G. (1998a). Planning for Coastline Change. 2a Determination of Coastal Development Setback Guidelines in Nevis. COSALC report: Coast and Beach Stability in the Caribbean Islands (p. 40). Coastal Regions and Small Islands Sea Grant College Programme, University of Puerto Rico.

Cambers, G. (1998b). Planning for Coastline Change. 2b Shoreline Management in Nevis: A Position Paper. COSALC report: Coast and Beach Stability in the Caribbean Islands (p. 42). Coastal Regions and Small Islands Sea Grant College Programme, University of Puerto Rico.

Chauhan, O. S., Verma, V. K., \& Prasad, C. (1988). Variations in Mean Grain Size as Indicators of Beach Sediment Movement at Puri and Konark Beaches, Orissa, India. Journal of Coastal Research, 4(1), 27-35.

Darsan, J. (2005). A comparative study of the coastal geomorphology of Cocos Bay and Las Cuevas Bay, Trinidad. Caribbean Geography, 14(2), 116-132.

Darsan, J. (2013a). Beach Morphological Dynamics at Cocos Bay (Manzanilla), Trinidad. Atlantic Geology, 49, 151-168. http://dx.doi.org/10.4138/atlgeol.2013.008

Darsan, J. (2013b). Beach State Classification; The Dissipative Domain of Cocos Bay, (Manzanilla), Trinidad. Caribbean Journal of Earth Science, 46, 1-11. Retrieved from http://caribjes.com/CJESpdf/CJES46-01-DarsanBeach.pdf

Darsan, J., Asmath, H., \& Jehu, A. (2013). Flood-risk Mapping for Storm Surge and Tsunami at Cocos Bay (Manzanilla), Trinidad. Journal of Coastal Conservation, 17(3), 679-689. http://dx.doi.org/10.1007/s11852-013-0276-x

Darsan, J., Ramnath, S., \& Alexis, C. (2012). Status of beaches and bays in Trinidad 2004-2008, Technical Report (p. 214). Hilltop Lane, Chaguaramas: Institute of Marine Affairs.

Deane, C. A. W. (1973). In Ministry of Planning and Development and Ministry of Works (Ed.), Coastal Erosion Point Fortin to Los Gallos: Final Report: Columbus Bay (p. 61). Hilltop Lane, Chaguaramas: Institute of Marine Affairs.

Elmoustapha, A. O., Levoy, F., Manfort, O., \& Koutitonsky, V. G. (2007). A numerical forecast of shoreline evolution after harbour construction in Nouakchott, Mauritania. Journal of Coastal Research, 23(6), 1409-1417. http://dx.doi.org/10.2112/04-0423.1

Elsayed, M. A. K., \& Mahmoud, S. M. (2007). Groins System for Shoreline Stabilization on the East Side of the Rosetta Promontory, Nile Delta Coast. Journal of Coastal Research, 23(2), 380-387. http://dx.doi.org/10.2112/04-0319.1

Farris, A. S., \& List, J. H. (2007). Shoreline Change as a Proxy for Subaerial Beach Volume Change. Journal of Coastal Research, 23(3), 740-748. http://dx.doi.org/10.2112/05-0442.1

Febres-Ortega, G., \& Herrera, L. E. (1976). Caribbean Sea Circulation and water mass transports near the Lesser Antilles. Boletin del Instituto Oceanografico, 15(1), 83-96.

Fratantoni, D. M., \& Richardson, P. L. (2006). The Evolution and Demise of North Brazil Current Rings. Journal of Physical Oceanography, 36(7), 1241-1264. http://dx.doi.org/10.1175/JPO2907.1 
Geological Society of Trinidad and Tobago. (1997). Geological Map 1997. Retrieved November 4, 2013, from http://www.gstt.org/map/map_600.jpg

Gopaul, N., \& Wolf, J. (1995). Development of a circulation model of the Gulf of Paria - Final Report (p. 40). Hilltop Lane, Chaguaramas: Institute of Marine Affairs.

Goudie, A., Anderson, M., Burt, T., Lewin, J., Richards, K., Whally, B., \& Worsely, P. (1990). Geomorphological Techniques (p. 570). Routledge.

Griggs, G. B. (2004). Headlands and Groins: Replicating Natural Systems. Journal of Coastal Research, Special Issue(33), 280-293.

Hanson, H., \& Kraus, N. C. (1989). GENESIS: Generalized Numerical Modelling System for Simulating Shoreline Change; Report 1, Technical Reference Manual. Technical Report CERC-89-19 (p. 16). Vicksburg, MS U.S. Army Engineer Waterways Experiment Station.

Henry, E. B. (1990). Climate Variability and Climate Change - the Role of Small Island State, Trinidad and Tobago. Trinidad and Tobago Climate Meteorological Division (p. 20). Ministry of Planning and Development, GORTT.

Hudson, D. (1988). Recent Sedimentation Patterns in Trinidad and Tobago (p. 10). Hilltop Lane, Chaguaramas: Institute of Marine Affairs.

Juman, R., \& Ramsewak, D. (2010). Status of mangrove forests in Trinidad and Tobago (p. 119). Hilltop Lane, Chaguaramas: Institute of Marine Affairs.

Kanhai, A. (2009). Coastal Regression and Transgression from Fullerton to Quemada Point in the South Western Peninsula of Trinidad and Tobago (p. 142). Department of Civil Engineering, University of the West Indies, St. Augustine.

Kenny, J. S. (2002). The Changing Coastline of the Cedros Peninsula, Trinidad. Living World: Journal of the Trinidad Field Naturalists' Club 2002, 1-7.

Kenny, J. S. (2007). The Re-shaping of Icacos Point 1797-2007 (p. 30). A review and analysis of the process involved.

Kökpinar, M. A., Darama, Y., \& Güler, I. (2007). Physical and Numerical Modelling of Shoreline Evaluation of the Kizilirmak River Mouth, Turkey. Journal of Coastal Research, 23(2), 445-456. http://dx.doi.org/10.2112/04-0178.1

Kraus, N. C., \& Rankin, K. L. (2004). Foreword: Functioning and Design of Coastal Groins: The Interaction of Groins and the Beach: Processes and Planning. Journal of Coastal Research, Special Issue(33), 1-2.

London Admiralty. (1965). Approaches to Trinidad including the Gulf of Paria. United Kingdom Hydrographic Office. Sheet 493.

Masselink, G., \& Hughes, M. G. (2003). Introduction to coastal processes and geomorphology. New York: Oxford University Press Inc.

McSweeney, C., New, M., \& Lizcano, G. (2008). UNDP Climate Change Country Profiles, Trinidad and Tobago. Retrieved November 4, 2013, from http://ncsp.undp.org/sites/default/files/Trinidad_and_Tobago.oxford.report.pdf

Mohanty, P. K., Patra, S. K., Bramha, S., Seth, B., Pradhan, U., Behera, B., ... Panda, U. S. (2012). Impact of groins on beach morphology: a case study near Gopalpur Port, east coast of India. Journal of Coastal Research, 28(1), 132-142. http://dx.doi.org/10.2112/JCOASTRES-D-10-00045.1

Nielsen, L. (2001). Newcastle Coastal Zone Management Plan: Coastal Engineering Advice. Technical Report for Umwelt (Australia) Pty Ltd.

Oostdam, B. L. (1982). Columbus Bay - Coastal Erosion and Accretion at Corral Point, S.W. Trinidad (p. 10). Hilltop Lane, Chaguaramas: Institute of Marine Affairs.

Pilarczyk, K. W., \& Zeidler, R. B. (1996). Offshore Breakwaters and Shore Evolution Control (p. 560). A. A. Balkema.

Reeve, D., Chadwick, A., \& Fleming, C. (2004). Coastal Engineering: Processes, Theory and Design Practice (p. 461). Spon Press,.

Sabastien, C. (2010). Interview by C. Alexis on the impact of coastal erosion on the coconut estates at Columbus 
Bay on 5 March, 2010.

Schneider, C. (1981). The Littoral Environment Observation (LEO) Data Collection Programme. Coastal Engineering Technical Aid No. 85-5. Vicksburg, Mississippi: U.S. Army Engineering Research Centre. http://dx.doi.org/10.5962/bhl.title.47406

USACE, United States Army Corps of Engineers. (1977). Shore Protection Manual (p. 651). Ft. Belvoir, VA: Coastal Engineering Research Center.

USACE, United States Army Corps of Engineers. (1995). Design of Coastal Revetments, Seawalls, and Bulkheads (p. 112). US Army Corps of Engineers.

USACE, United States Army Corps of Engineers. (2002). In U. S. A. C. o. Engineers (Ed.), Coastal Engineering Manual. Engineer Manual 1110-2-1100 (6 vols.). Washington, D.C.

USACE, United States Army Corps of Engineers. (2006). Coastal engineering manual. U.S. Army Corps of Engineers. Retrieved from http://www.knovel.com/knovel2/Toc.jsp?BookID=1326

Van Andel, T. H., \& Postma, H. (1954). Recent sediments of the Gulf of Paria: reports of the Orinoco Shelf Expedition (p. 244). Amsterdam: North-Holland Pub. Co.

\section{Copyrights}

Copyright for this article is retained by the author(s), with first publication rights granted to the journal.

This is an open-access article distributed under the terms and conditions of the Creative Commons Attribution license (http://creativecommons.org/licenses/by/3.0/). 